\title{
Effect of bacterial consortia on growth and yield of maize grown in Fusarium infested soil
}

\author{
Naseem Akhtarl, Muhammad Naveed ${ }^{2}$, Muhammad Khalid $^{2}$, Nisar Ahmad', \\ Muhammad Rizwan ${ }^{3}$ and Saima Siddique $e^{3}$ \\ ${ }^{1}$ Biochemistry Section, Post-Harvest Research Center, AARI, Faisalabad \\ ${ }^{2}$ Institute of Soil \& Environmental Sciences, University of Agriculture, Faisalabad \\ ${ }^{3}$ Applied Chemistry Research Centre, PCSIR laboratories Complex, Lahore
}

\begin{abstract}
Soil borne pathogens are responsible for considerable yield losses in field crops. Healthy growth and ultimate yield of the crop depends upon the efficient supply of water, nutrients and absence of biotic and abiotic stress. Under biotic stress plant growth promoting rhizobacteria (PGPR) and compost inhabiting bacteria (CIB) can help the plant to function normally by suppressing the pathogen. A pot experiment was conducted to determine the effect of PGPR and CIB on growth and yield of maize, grown in fungus infested soil. Two strains, each of PGPR (Mb4 and Mb7) and CIB (Cb4 and Cb9) were evaluated to improve the growth and yield of maize crop. Maize seeds were sterilized and inoculated with bacterial strains before sowing along with un-inoculated control for comparison. Recommended dose of fertilizers $\left(180,140,90 \mathrm{NPK} \mathrm{kg} \mathrm{ha}^{-1}\right)$ was applied at sowing and pots were arranged in completely randomized design. Results showed that inoculation with selected strains of bacteria, exhibited percent increase in yield of fresh cob (up to 52.69\%) and dry cob (40.87\%), cob length (51.42\%), grain yield (up to 55.34\%), 1000-grain weight (up to 37.27\%), K contents in grains and straw (1.756 and 0.793, respectively), $\% \mathrm{~N}$ in grains and straw (up to 2.675 and $0.997 \%$, respectively) and \%P in grains and straw (up to 1.756 and $0.793 \%$, respectively) compared to un-inoculated control. Keeping in view the higher yield parameters of inoculated treatments compared to un-inoculated control, it was concluded that inoculation of maize seeds with bacterial consortia suppressed the adverse effect of fungal pathogen and enhanced the growth and yield of maize crop.
\end{abstract}

Keywords: Bacterial consortia, PGPR, CIB, Fusarium oxysporum, maize

\section{Introduction}

Microbes are everywhere on the earth but the largest number of microbes reside in the rhizosphere (Carmen and Roberto, 2011). Among this microbial population, bacteria and fungi cover the highest proportion (Morgan et al., 2005). They compete with each other for food and space and differ from the microbes residing in the bulk soil (Chaparro et al., 2013). Rhizospheric bacteria are very important for proper development of plants under stressed conditions. They can be plant specific and their number can vary with age of plant, type of soil and environmental conditions (Hrynkiewicz et al., 2010; Bouffaud et al., 2012). Their effect on plants may be detrimental, beneficial or neutral (Katarzyna and Christel, 2011). Detrimental microbes may be major plant pathogens and/or minor parasites while favorable bacteria help plants to grow successfully (Bulgarelli et al., 2013).

Seedling blight in maize crops is due to soil born fungus Fusarium oxysporum. Different Fusarium species cause seedling blight, crown rot and scab of wheat and barley, stalk, cob and crown rot of maize (Khan et al.,
2006). Seed infected with Fusarium, exhibited reduced germination, seedling emergence and caused post emergence death of wheat seedling and ear rot of maize (Charles et al., 2007).

Seed treatment with pesticide could be effective for control of pathogens but more severe problems may arise due to lethal residues of fungicides (Cardoso et al., 2010). The continuous use of pesticides is not only deteriorating the environment but also has increased the resistance in the pests (Gassmann et al., 2011). Extensive use of pesticide might cause soil and air pollution which might have adverse effects on the human, animals and plants health. The persistent nature of many pesticide/fungicides further aggravated the problem. Sometimes pesticides may activate into more harmful by-products that might cause more serious health problems due to their uptake by plant and ultimately by entering into the food chain (Wasim et al., 2009). Therefore, biocontrol may be the best alternative of chemical control for plant diseases (Killani et al., 2011) being economical and environment friendly (Lugtenberg and Kamilova, 2009).

\footnotetext{
*Email: nasimsajjad235@gmail.com
} 
Beneficial bacteria (PGPR, CIB) colonize the plant root surface and increase nutrient uptake (Jing et al., 2007), release organic compounds (Shukla et al., 2011; Drogue et al., 2013) and suppress the diseases (Tarkka et al., 2008) resultantly improve the growth of plants. They produce antimicrobial metabolites and induce systemic resistance in plants (Falahian et al., 2007; Erdogan and Benlioglu, 2010). Plant growth promoting rhizobacteria help plants by modifying the chemical composition of root cell wall (El Zemrany et al., 2007) and by amplifying the lignin deposition in epidermal tissues of inoculated plants under diseased condition (Niranjan et al., 2012).

Inoculation of field crops with compatible strains showed better results than single inoculation (Figueiredo et al., 2010). Inoculation with PGPR and arbuscular mycorrhizal fungi enhanced the yield of sorghum (Kumar et al., 2012). Inoculation with a consortium of two PGPR and one mycorrhizal strain exhibited enhanced growth of root in maize crop (Walker et al., 2012). In the present study bacterial strains were characterized for siderophore and chitinase production, biofilm formation and antagonism assay and the efficient strains were used to evaluate the potential of bacterial consortia for yield and growth promotion of maize crop in fungus infested soil.

\section{Materials and Methods \\ Isolation of bacteria}

Bacteria were isolated using standard dilution-plating procedure as described by Pugliese et al. (2008). Ten gram of the sample (Compost/rhizosphere soil) was mixed with $90 \mathrm{~mL}$ of sterile distilled water in conical flask, shaken vigorously on a vortex mixer for 10 minutes and serially diluted up to $10^{-9}$. An aliquot $(0.1 \mathrm{~mL})$ of these suspensions was spread on the plates of Luria-Bertani (LB) agar medium (Luria and Burrous, 1995). Inoculated plates were incubated at $26 \pm 2^{\circ} \mathrm{C}$ for $48 \mathrm{~h}$ and were purified by repeated streaking on the same medium until pure colonies were established.

\section{Cross check of pathogen}

The pathogen (Fusarium oxysporum) was collected from Department of Plant Pathology, Ayub Agricultural Research Institute, Faisalabad, isolated by tissue segment method and identified by using colony morphology and microscopic features. Pathogenicity was tested on live plant by cut stem method (Singh et al., 1991). The mycelial suspension of the isolates was produced in broth medium of $250 \mathrm{~mL}$ in conical flasks. The mycelium of the isolate was filtered through the cheesecloth by gentle pressing to remove excess liquid and blending for 30 seconds in blender at the rate of $5 \mathrm{~g}$ of mycelium per liter of sterile deionized water. The resulting suspension was used as inoculum. The inoculum was freshly prepared before the applications. Three weeks old seedlings of maize, grown in sterilized potted soil were inoculated with the mycelial suspension of the fungal isolate. The pathogen was reisolated from the infected plants and identified using colony morphology and microscopic features (Singh et al., 1991) and compared the characteristics with the initial isolates.

\section{Characterizations of bacterial isolates}

Seventy five strains of each PGPR and CIB were isolated from maize rhizosphere and compost, respectively. Twenty five strains were selected for preliminary tests (in vitro disease suppression assay), and two each of PGPR (Mb1 to $\mathrm{Mb} 25)$ and $\mathrm{CIB}$ ( $\mathrm{Cb} 1$ to $\mathrm{Cb} 25)$ were selected for further evaluation under pot condition. The selected strains were further characterized for beneficial plant growth promoting traits following standard methods as mentioned in Bergey's Manual of Systematic Bacteriology (Krieg and Holt, 1984). Bacterial strains (Mb4, Mb7, Cb4 and Cb9) were characterized for siderophore production and chitinase activities, by following the protocols described by Clark and Bavoil (1994) and Chernin et al. (1998) respectively. Biofilm formation was carried out by following the procedure adopted by Peeters et al. (2008).

\section{Antagonism assay}

The target pathogen was inoculated on PDA at four equidistant peripheral points while compost inhabiting bacteria were inoculated at the center of Petri plates. In another set, the target pathogens were inoculated at the center and CIB at four equidistant peripheral points of Petri plates. Same was repeated for the PGPR in place of compost inhabiting bacteria. The experiment was replicated thrice and incubated at $28 \pm 1{ }^{\circ} \mathrm{C}$. Inhibition of pathogens was observed after every $12 \mathrm{~h}$. The means of the three measurements were recorded for each pathogen. Inhibition of pathogen $(\%)$ over control was calculated by using the following formula (Vincent, 1947),

$$
\begin{gathered}
\text { Percent } \\
\text { Inhibition of mycelium }(\mathrm{I})=\frac{\mathrm{C}-\mathrm{T}}{\mathrm{C}} \times 100
\end{gathered}
$$

Where ' $\mathrm{I}$ ' is percent inhibition of mycelium, ' $\mathrm{C}$ ' is growth of mycelium in control and ' $\mathrm{T}$ ' is growth of mycelium in inoculated treatment.

\section{Preparation of inoculum and seed inoculation}

Inocula of selected strains of PGPR (Mb4 and Mb7) and $\mathrm{CIB}$ (Cb4 and $\mathrm{Cb} 9$ ) were prepared separately in 250 $\mathrm{mL}$ conical flask having $100 \mathrm{~mL}$ LB broth. The inoculated culture was incubated at $28 \pm 1^{\circ} \mathrm{C}$ in the orbital shaking incubator at $100 \mathrm{rpm}$ for 48 hours. An optical density of 
0.5 , recorded with an optical density meter at wavelength of $535 \mathrm{~nm}$ was achieved by dilution to maintain uniform cell density $\left(10^{8}-10^{9} \mathrm{CFU} \mathrm{mL}^{-1}\right)$ prior to seed inoculation. A consortium was prepared by mixing bacterial strains cultures in 1:1 ratio. The seeds of maize were inoculated by coating with peat-based slurry containing 2-days old inocula of respective strains and sugar solution (10\%). Whereas the seeds for control were treated with peat containing sterilized broth and solution of sugar (Yadav et al., 2010). Inoculated seeds were air dried under shade before sowing. Fusarium oxysporum culture was prepared in $250 \mathrm{~mL}$ flak contain potato dextrose broth (PDB)

\section{Pot experiment}

Pot experiment was carried out in sandy clay loam soil having $\mathrm{pH}, 7.9$; EC, $1.4 \mathrm{dS} \mathrm{m}^{-1}$; nitrogen, $0.030 \%$; available phosphorus, $7.2 \mathrm{mg} \mathrm{kg}^{-1}$ and extractable $\mathrm{K} 120 \mathrm{mg} \mathrm{kg}^{-1}$ at wire house of Soil Bacteriology Section, Agriculture Biotechnology Research Institute, AARI, Faisalabad. Each pot contained $12 \mathrm{~kg}$ soil. Recommended dose of NPK fertilizers $\left(180,140,90 \mathrm{NPK} \mathrm{kg} \mathrm{ha}{ }^{-1}\right)$ was applied as urea,

suppression and growth promotion was collected during the growth period while yield data was collected at harvest.

Grains and straw samples were digested using tri-acid mixture (nitric acid, sulfuric acid and perchloric acid (9:2:1 $(\mathrm{v} / \mathrm{v})$ ) and analyzed phosphorus and potassium following protocol given by Ryan et al. (2001). Soil and plant samples were digested with sulfuric acid and catalyst mixtures following Gunning and Hibbard's method and for the distillation of ammonia into nitrogen, $4 \%$ boric acid was utilized using macro Kjeldhal's apparatus (Jackson, 1967) while available phosphorus was determined by Olsen method (Olsen and Sommer, 1982). Extractable potassium was determined using flame photometer Jenway PFP-7.

\section{Statistical analysis}

Standard errors of means of the data were computed following Steel et al. (1997) using the statistical software STATISTIX v8.1 whilst means were compared by means of Duncan's Multiple Range Test (Duncan, 1955).

Table1: Characterization of PGPR and CIB isolates

\begin{tabular}{|c|c|c|c|c|c|}
\hline \multirow[t]{2}{*}{ Treatment } & \multirow[t]{2}{*}{$\begin{array}{c}\text { Siderophore } \\
\text { production }\end{array}$} & \multirow[t]{2}{*}{ Chitinase } & \multirow[t]{2}{*}{$\begin{array}{l}\text { Antagonism } \\
\text { (I \%) }\end{array}$} & \multicolumn{2}{|c|}{$\begin{array}{c}\text { Biofilm formation } \\
\text { Absorbance }\end{array}$} \\
\hline & & & & $600 \mathrm{~nm}$ & $595 \mathrm{~nm}$ \\
\hline Mb4 & ++ & ++ & 84 & 4.095 & 2.971 \\
\hline Mb5 & - & - & 84 & 2.018 & 1.775 \\
\hline Mb6 & ++ & - & 82 & 2.508 & 1.556 \\
\hline $\mathrm{Mb} 7$ & ++ & ++ & 81 & 3.314 & 2.860 \\
\hline $\mathrm{Cb} 1$ & - & ++ & 86 & 2.341 & 1.29 \\
\hline $\mathrm{Cb} 4$ & ++ & ++ & 86 & 3.210 & 2.78 \\
\hline $\mathrm{Cb} 8$ & - & ++ & 88 & 2.117 & 1.56 \\
\hline $\mathrm{Cb} 9$ & ++ & ++ & 86 & 4.081 & 2.54 \\
\hline
\end{tabular}

Mb4= Bacillus megaterium, Mb7= Pseudomonas aeruginosa, Cb4= Serratia spp., Cb9= Pseudomonas fluorescens

single super phosphate, and sulphate of potash). The whole $\mathrm{P}$ and $\mathrm{K}$ were supplemented as basal dose whereas $\mathrm{N}$ was added in two splits (Once after germination and then at tasseling stage). Equal volume of fungus (Fusarium oxysporum) inoculum $\left(10^{6}\right.$ spores $\left.\mathrm{mL}^{-1}\right)$ was added at the time of pot filling by mixing manually into soil. Surface disinfected maize seeds were inoculated by peat based inocula/slurry (consist of peat, sugar and bacterial culture, multiplied on LB broth media) while control was treated with slurry prepared with peat, sugar and LB broth without bacteria cells (un-inoculated). Seed of each treatment was sown at the depth of $3.81 \mathrm{~cm}$. Each treatment was replicated thrice and arranged according to completely randomized design. Good quality canal water $\left[\mathrm{EC}=0.7 \mathrm{dS} \mathrm{m}^{-1}, \mathrm{SAR}=\right.$ $0.5\left(\mathrm{mmol} \mathrm{L}^{-1}\right) 1 / 2$ and $\left.\mathrm{RSC}=0.05 \mathrm{mmolc} \mathrm{L}^{-1}\right]$ meeting the irrigation quality criteria for crops (Ayers and Westcot 1985) was used for irrigation. Data regarding disease

\section{Results}

\section{Characterization of PGPR and CIB}

All the isolates $(\mathrm{Mb} 4, \mathrm{Mb} 7, \mathrm{Cb} 4$, and $\mathrm{Cb} 9)$ were characterized for siderophore production, chitinase production, antagonistic effect against Fusarium oxysporum and biofilm formation (Table 1). Four strains i.e. $\mathrm{Mb} 4, \mathrm{Mb} 7, \mathrm{Cb} 4, \mathrm{Cb} 9$ were proficient siderophore producers and showed efficient chitinase activity. Percent antagonism by $\mathrm{Mb} 4$ and $\mathrm{Mb} 7$ ranged from 82 to $84 \%$ and it varied from 86 to $88 \%$ by $\mathrm{Cb} 4$ and $\mathrm{Cb} 9$. Biofilm formation at absorbance of 595 and $600 \mathrm{~nm}$ was observed and results showed that Mb4 (4.095, $2.971 \mathrm{~nm}), \mathrm{Mb} 7$ $(3.314,2.860 \mathrm{~nm}), \mathrm{Cb} 4(3.210,2.78 \mathrm{~nm})$ and $\mathrm{Cb} 9$ (4.081, $2.54 \mathrm{~nm}$ ) were efficient for biofilm formation at both the wavelengths while $\mathrm{Cb} 9$ was the most effective strain for biofilm formation. 


\section{Effect of bacterial consortia on growth parameters of maize}

Leaf size is related to photosynthesis of the plant, so health of the crop is affected by leaf area. Leaf length was positively affected by bacterial inoculation. Increase in leaf maximum leaf length was recorded with consortium of all the four strains $(88.40 \mathrm{~cm})$ compared to control $(62.2 \mathrm{~cm})$. All the inoculated treatments showed leaf width, significantly higher than control. Maximum leaf width was recorded with consortium of four $(7.9 \mathrm{~cm})$ followed by $\mathrm{Mb} 4$ + $\mathrm{Cb} 4+\mathrm{Cb} 9$ (7.87 cm), Mb7 + Cb4 + Cb9 (7.7 cm) and

Table 2: Effect of consortium of bacterial strains on leaf length, leaf width and intermodal distance of maize grown in fungus infested soil

\begin{tabular}{|c|c|c|c|c|}
\hline Treatment & $\begin{array}{l}\text { Leaf length } \\
(\mathrm{cm})\end{array}$ & $\begin{array}{l}\text { Leaf width } \\
(\mathrm{cm})\end{array}$ & $\begin{array}{l}\text { Leaf area } \\
\left(\mathrm{cm}^{2}\right)\end{array}$ & $\begin{array}{l}\text { Inter-nodal } \\
\text { distance }(\mathrm{cm})\end{array}$ \\
\hline Control & $62.20 \mathrm{~h}$ & $3.90 \mathrm{k}$ & $242.18 \mathrm{~h}$ & $10.20 \mathrm{c}$ \\
\hline Mb4 & $78.50 \mathrm{efg}$ & $5.70 \mathrm{j}$ & $447.15 \mathrm{~g}$ & $13.50 \mathrm{ab}$ \\
\hline Mb7 & $75.30 \mathrm{~g}$ & $6.00 \mathrm{ij}$ & $452.00 \mathrm{~g}$ & $13.40 \mathrm{abc}$ \\
\hline $\mathrm{Cb} 4$ & $78.03 \mathrm{fg}$ & $6.6 \mathrm{fgh}$ & $514.8 \mathrm{ef}$ & $12.20 \mathrm{bc}$ \\
\hline $\mathrm{Cb} 9$ & $79.90 \mathrm{ef}$ & $6.27 \mathrm{hi}$ & 529 def & $12.90 \mathrm{abc}$ \\
\hline $\mathrm{Mb} 4+\mathrm{Cb} 4$ & 80.90 def & 7.13 cde & $576.89 \mathrm{bc}$ & $12.90 \mathrm{abc}$ \\
\hline $\mathrm{Mb} 4+\mathrm{Cb} 9$ & 82.00 cde & $6.73 \mathrm{efg}$ & $552.27 \mathrm{cde}$ & $13.00 \mathrm{abc}$ \\
\hline $\mathrm{Mb} 7+\mathrm{Cb} 4$ & $81.90 \mathrm{cde}$ & $6.63 \mathrm{fgh}$ & $543.67 \mathrm{c}-\mathrm{f}$ & $12.50 \mathrm{abc}$ \\
\hline $\mathrm{Mb} 7+\mathrm{Cb} 9$ & $81.7 \mathrm{cdef}$ & $6.6 \mathrm{fgh}$ & $536 \mathrm{c}-\mathrm{f}$ & $13.70 \mathrm{ab}$ \\
\hline $\mathrm{Mb} 4+\mathrm{Cb} 4+\mathrm{Cb} 9$ & $86.00 \mathrm{ab}$ & $7.87 \mathrm{ab}$ & $663.00 \mathrm{a}$ & $14.60 \mathrm{ab}$ \\
\hline $\mathrm{Mb} 7+\mathrm{Cb} 4+\mathrm{Cb} 9$ & $85.30 \mathrm{abc}$ & $7.70 \mathrm{ab}$ & $656.81 \mathrm{a}$ & $15.0 \mathrm{ab}$ \\
\hline $\mathrm{Cb} 4+\mathrm{Mb} 4+\mathrm{Mb} 7$ & $84.4 \mathrm{~b} \mathrm{~cd}$ & $7.43 \mathrm{bcd}$ & $594.26 \mathrm{~b}$ & $13.70 \mathrm{ab}$ \\
\hline $\mathrm{Cb} 9+\mathrm{Mb} 4+\mathrm{Mb} 7$ & $85.50 \mathrm{bc}$ & $7.50 \mathrm{abc}$ & $675.45 \mathrm{a}$ & $14.40 \mathrm{ab}$ \\
\hline Consortium of all the four strains & $88.40 \mathrm{a}$ & $7.90 \mathrm{a}$ & $676.82 \mathrm{a}$ & $15.50 \mathrm{a}$ \\
\hline LSD & 3.8250 & 0.4347 & 41.736 & 3.2027 \\
\hline
\end{tabular}

Means sharing the same letter are not significantly different from each other (data is the mean of three repeats)

$\mathrm{Mb} 4=$ Bacillus megaterium, $\mathrm{Mb} 7=$ Pseudomonas aeruginosa, $\mathrm{Cb} 4=$ Serratia $\mathrm{spp} ., \mathrm{Cb} 9=$ Pseudomonas fluorescens

Table 3: Effect of consortium of bacterial strains on stem diameter, plant height, root length and shoot dry weight of maize grown in fungus infested soil

\begin{tabular}{|c|c|c|c|c|}
\hline Treatment & $\begin{array}{l}\text { Stem diameter } \\
(\mathrm{mm})\end{array}$ & $\begin{array}{l}\text { Plant height } \\
\text { (cm) }\end{array}$ & $\begin{array}{l}\text { Root length } \\
\text { (cm) }\end{array}$ & $\begin{array}{l}\text { Shoot dry Weight (g } \\
\left.\mathrm{pl}^{-1}\right)\end{array}$ \\
\hline Control & $8.40 \mathrm{i}$ & $131.2 \mathrm{hi}$ & $65.00 \mathrm{f}$ & $41.50 \mathrm{ef}$ \\
\hline Mb4 & $9.30 \mathrm{~h}$ & $137.7 \mathrm{efg}$ & 69.00def & $44.44 \mathrm{de}$ \\
\hline $\mathrm{Mb} 7$ & $9.50 \mathrm{gh}$ & $135.9 \mathrm{gh}$ & $70.33 \mathrm{def}$ & $44.17 \mathrm{de}$ \\
\hline $\mathrm{Cb} 4$ & $9.70 \mathrm{fg}$ & $136.7 \mathrm{fg}$ & $67.00 \mathrm{ef}$ & $45.51 \mathrm{de}$ \\
\hline $\mathrm{Cb} 9$ & $9.90 \mathrm{f}$ & $137.4 \mathrm{fg}$ & $70.67 \mathrm{de}$ & 45.61de \\
\hline $\mathrm{Mb} 4+\mathrm{Cb} 4$ & $10.47 \mathrm{~d}$ & $140.0 \mathrm{defg}$ & $71.34 \mathrm{cbe}$ & $47.45 \mathrm{~cd}$ \\
\hline $\mathrm{Mb} 4+\mathrm{Cb} 9$ & $10.50 \mathrm{~d}$ & $142.5 \mathrm{cde}$ & $73.67 \mathrm{bcd}$ & $48.70 \mathrm{bcd}$ \\
\hline $\mathrm{Mb} 7+\mathrm{Cb} 4$ & $10.30 \mathrm{de}$ & $137.3 \mathrm{fg}$ & $73.65 \mathrm{bcd}$ & $48.23 \mathrm{bcd}$ \\
\hline $\mathrm{Mb} 7+\mathrm{Cb} 9$ & 9.93 ef & $140.7 \mathrm{def}$ & $76.67 \mathrm{bc}$ & $49.00 \mathrm{bcd}$ \\
\hline $\mathrm{Mb} 4+\mathrm{Cb} 4+\mathrm{Cb} 9$ & $11.70 \mathrm{bc}$ & $143.7 \mathrm{~cd}$ & $77.67 \mathrm{~b}$ & $53.22 \mathrm{ab}$ \\
\hline $\mathrm{Mb} 7+\mathrm{Cb} 4+\mathrm{Cb} 9$ & $12.40 \mathrm{~b}$ & $147.4 \mathrm{abc}$ & $86.65 a$ & $54.74 \mathrm{a}$ \\
\hline $\mathrm{Cb} 4+\mathrm{Mb} 4+\mathrm{Mb} 7$ & $12.50 \mathrm{~b}$ & $145.7 \mathrm{bc}$ & $85.33 \mathrm{a}$ & $54.80 \mathrm{a}$ \\
\hline $\mathrm{Cb} 9+\mathrm{Mb} 4+\mathrm{Mb} 7$ & $12.27 \mathrm{~b}$ & $150.7 \mathrm{a}$ & $83.55 \mathrm{a}$ & $54.83 \mathrm{a}$ \\
\hline $\begin{array}{l}\text { Consortium of all the four } \\
\text { strains }\end{array}$ & $13.30 \mathrm{a}$ & $149.4 \mathrm{ab}$ & $87.00 \mathrm{a}$ & $55.55 \mathrm{a}$ \\
\hline LSD & 0.3964 & 4.8463 & 5.6166 & 5.2626 \\
\hline
\end{tabular}

Means sharing the same letter are not significantly different from each other (data is the mean of three repeats)

$\mathrm{Mb} 4=$ Bacillus megaterium, $\mathrm{Mb} 7=$ Pseudomonas aeruginosa, $\mathrm{Cb} 4=$ Serratia $\mathrm{spp} ., \mathrm{Cb} 9=$ Pseudomonas fluorescens

area was higher by single inoculation but combination of two and three strains of $\mathrm{Mb}$ and $\mathrm{Cb}$ gave better result while
$\mathrm{Cb} 9+\mathrm{Mb} 4+\mathrm{Mb} 7(7.5 \mathrm{~cm})$ which were significantly higher than control $(3.9 \mathrm{~cm})$. Inoculated treatments gave 
higher leaf surface area than un-inoculated control (242.18 $\mathrm{cm}^{2}$ ). Inter-nodal distance, stem diameter and plant height was higher by inoculated treatments, however effect of single inoculation was less than the consortium of two and three strains while maximum increase was observed with consortium of all the four strains.

Root length is related to healthy growth of the plant because it anchors the plant and enables it to uptake required amount of water and nutrients. Root length was increased by inoculation with bacterial consortia compared to un-inoculated control. Longest root was observed by inoculation with consortium of all the four strains $(87 \mathrm{~cm})$, medium length was with consortium of $\mathrm{Mb} 7$ with $\mathrm{Cb} 4$ and Cb9 and smaller with single inoculation however all the inoculated treatments showed longer root than control (65 $\mathrm{cm})$. Shoot dry weight was also higher by inoculation with bacterial consortium of all the four strains (55.55 g plant $^{-1}$ ) which was statistically at par with consortium of $\mathrm{Cb} 9$ with Mb4 and Mb7 and significantly better than single strain inoculation.

\section{Effect of bacterial consortia on yield parameters of maize}

Cob weight was affected by inoculation with bacterial consortia. Fresh cob weight was higher by inoculation with consortium of four strains (107.45 $\mathrm{g} \mathrm{cob}^{-1}$ ) which were statistically at par with consortium of $\mathrm{Cb} 4$ and $\mathrm{Cb} 9$ with Mb4 and Mb7 showing 52.69, 49.4 and 47.98\% increase respectively over control. Eminent increase in cob weight was also observed by inoculation with consortium of two and three strains which were significantly higher than single treatments. Consortium of all the four strains showed $40.87 \%$ increase in cob weight followed by consortium of $\mathrm{Cb} 9$ with $\mathrm{Mb} 4$ and $\mathrm{Mb} 7$ which showed $39.78 \%$ increase over control. Percent increase in dry cob weight ranged from $39.78 \%$ by consortium of triple strains to $28.29 \%$ by consortium of two strains while single strain inoculation showed increase up to $22.06 \%$ (Cb9). Highest cob length was observed with consortium of four which showed $51.42 \%$ increase over control. Cob length ranged from 15 to $17.33 \mathrm{~cm}$ by consortium of three strains while cob length with consortium of two strains ranged from 13.34 to 14.67 $\mathrm{cm}$ and was significantly higher than control $(12.33 \mathrm{~cm})$.

Grain yield is the ultimate capitulate and of actual interest. Grain yield was higher by all the inoculated treatments than control. Significantly higher grain yield $55.77 \mathrm{~g} \mathrm{cob}^{-1}$ was perceived by inoculation with consortium of all the four strains which showed $55.34 \%$ increase in grain yield while $37.27 \%$ increase in thousand grain weight over control. Other prominent values for thousand grain weight were $156,153.5$, and $153.34 \mathrm{~g}$, with consortium of different combination of three strains which was significantly higher than control (120.44 g).

\section{Effect of bacterial consortia on NPK contents of grain and straw of maize}

Inoculation positively affected the chemical composition of maize, grown in fungus infested soil. Percent nitrogen in grain $(2.675 \%)$, percent nitrogen of straw $(0.997 \%)$, phosphorus percentage in grain and straw

Table 4: Effect of consortium of bacterial strains on yield parameters of maize

\begin{tabular}{|c|c|c|c|c|c|}
\hline Treatment & $\begin{array}{l}\text { Fresh cob yield } \\
\left(\mathrm{g} \mathrm{cob}^{-1}\right)\end{array}$ & $\begin{array}{l}\text { Air dried cob yield } \\
\left(\mathrm{g} \mathrm{cob}^{-1}\right)\end{array}$ & Cob length (cm) & $\begin{array}{l}\text { Grain yield } \\
\left(\mathrm{g} \mathrm{cob}^{-1}\right)\end{array}$ & $\begin{array}{l}1000 \text { Grain } \\
\text { weight (g) }\end{array}$ \\
\hline Control & $70.37 \mathrm{i}$ & $45.60 \mathrm{~h}$ & $12.33 b$ & $35.90 \mathrm{f}$ & $120.44 \mathrm{~g}$ \\
\hline $\mathrm{Mb} 4$ & $91.5 \mathrm{fg}$ & $53.45 \mathrm{fg}$ & 14.33ab & $40.43 \mathrm{ef}$ & $132.1 \mathrm{de}$ \\
\hline Mb7 & $89.76 f g$ & $54.53 \mathrm{efg}$ & $13.45 b$ & 42.33def & $126.45 \mathrm{ef}$ \\
\hline $\mathrm{Cb} 4$ & $81.00 \mathrm{~h}$ & $50.31 \mathrm{gh}$ & $13.33 b$ & $42.01 \mathrm{def}$ & $126.6 \mathrm{ef}$ \\
\hline $\mathrm{Cb} 9$ & $90.98 \mathrm{fg}$ & $55.66 \mathrm{~d}-\mathrm{g}$ & $13.77 \mathrm{ab}$ & $40.37 \mathrm{ef}$ & $126.33 \mathrm{ef}$ \\
\hline $\mathrm{Mb} 4+\mathrm{Cb} 4$ & $97.77 \mathrm{cde}$ & $58.50 \mathrm{~b}-\mathrm{f}$ & 14.44ab & $45.43 \mathrm{cde}$ & $135.23 \mathrm{~d}$ \\
\hline $\mathrm{Mb} 4+\mathrm{Cb} 9$ & 97.98 cde & 58.99 a-e & $14.51 \mathrm{ab}$ & $44.55 \mathrm{def}$ & $132.34 d$ \\
\hline $\mathrm{Mb} 7+\mathrm{Cb} 4$ & 94.79 ef & $57.55 \mathrm{c}-\mathrm{f}$ & $14.67 \mathrm{ab}$ & 44.14def & $141.1 \mathrm{c}$ \\
\hline $\mathrm{Mb} 7+\mathrm{Cb} 9$ & $97.28 \mathrm{de}$ & $55.34 \mathrm{~d}-\mathrm{g}$ & $13.34 \mathrm{~b}$ & $47.31 \mathrm{bcd}$ & $137.0 \mathrm{~cd}$ \\
\hline $\mathrm{Mb} 4+\mathrm{Cb} 4+\mathrm{Cb} 9$ & $100.44 \mathrm{bcd}$ & $60.54 a-d$ & $15.00 \mathrm{ab}$ & $52.44 \mathrm{ab}$ & $150.7 \mathrm{~b}$ \\
\hline $\mathrm{Mb} 7+\mathrm{Cb} 4+\mathrm{Cb} 9$ & $102.85 \mathrm{abc}$ & $62.64 a b c$ & $17.33 \mathrm{ab}$ & $50.05 b c$ & $156.0 \mathrm{~b}$ \\
\hline $\mathrm{Cb} 4+\mathrm{Mb} 4+\mathrm{Mb} 7$ & $105.13 \mathrm{ab}$ & $62.54 \mathrm{abc}$ & $16.54 \mathrm{ab}$ & $50.44 \mathrm{bc}$ & $153.34 \mathrm{~b}$ \\
\hline $\mathrm{Cb} 9+\mathrm{Mb} 4+\mathrm{Mb} 7$ & $104.14 \mathrm{ab}$ & $63.74 \mathrm{ab}$ & $16.67 \mathrm{ab}$ & $51.41 \mathrm{ab}$ & $153.5 \mathrm{~b}$ \\
\hline $\begin{array}{l}\text { Consortium of all } \\
\text { the four strains }\end{array}$ & $107.45 \mathrm{a}$ & $64.24 \mathrm{a}$ & $18.67 \mathrm{a}$ & $55.77 \mathrm{a}$ & $165.34 \mathrm{a}$ \\
\hline LSD & 5.2163 & 5.4738 & 5.1064 & 5.3289 & 5.5473 \\
\hline
\end{tabular}

Means sharing the same letter are not significantly different from each other (data is the mean of three repeats)

$\mathrm{Mb} 4=$ Bacillus megaterium, $\mathrm{Mb} 7=$ Pseudomonas aeruginosa, $\mathrm{Cb} 4=$ Serratia spp., $\mathrm{Cb} 9=$ Pseudomonas fluorescens 
(1.411 and $0.793 \%$ respectively) and maximum potassium in grain $(1.756 \%)$ and straw $(1.064 \%)$ (Table 6) was recorded with the treatments, inoculated with consortium of all the four strains (Mb4, Mb7, Cb4 and $\mathrm{Cb} 9)$. Medium concentration of $\mathrm{N}, \mathrm{P}$ and $\mathrm{K}$ was observed in treatments, inoculated with consortium of three and lower with single inoculation. All the inoculated treatments showed higher phosphorus and potassium by grain and straw of maize was also higher in treatments, inoculated with consortium of four strains of bacteria (Table 5).

\section{Discussion}

Seedling blight suppresses the growth by blocking the vascular tissues of the plant. Plant growth promoting

Table 5 Effect of consortium of bacterial strains on chemical composition of grain and straw of maize

\begin{tabular}{|c|c|c|c|c|c|c|}
\hline Treatment & $\begin{array}{l}\% \mathrm{~N} \text { in } \\
\text { grains }\end{array}$ & $\begin{array}{l}\% \mathrm{~N} \text { in } \\
\text { straw }\end{array}$ & $\begin{array}{l}\% \mathrm{P} \text { in } \\
\text { grains }\end{array}$ & $\begin{array}{l}\% \mathrm{P} \text { in } \\
\text { straw }\end{array}$ & $\begin{array}{l}\% \mathrm{~K} \text { in } \\
\text { grains }\end{array}$ & $\begin{array}{l}\% \mathrm{~K} \text { in } \\
\text { straw }\end{array}$ \\
\hline Control & $1.69 \mathrm{j}$ & $0.677 \mathrm{k}$ & $0.937 \mathrm{k}$ & $0.483 \mathrm{~m}$ & 1.271 & $0.822 \mathrm{~m}$ \\
\hline Mb4 & $1.945 \mathrm{~g}$ & $0.753 \mathrm{i}$ & $1.097 \mathrm{i}$ & $0.607 \mathrm{j}$ & $1.4497 \mathrm{j}$ & $0.932 \mathrm{k}$ \\
\hline $\mathrm{Mb} 7$ & $1.92 \mathrm{~h}$ & $0.747 \mathrm{j}$ & $1.117 \mathrm{~h}$ & 0.5531 & $1.43 \mathrm{k}$ & $0.933 \mathrm{k}$ \\
\hline $\mathrm{Cb} 4$ & $1.887 \mathrm{i}$ & $0.767 \mathrm{~h}$ & $1.067 \mathrm{j}$ & $0.58 \mathrm{k}$ & $1.44 \mathrm{jk}$ & 0.8931 \\
\hline $\mathrm{Cb} 9$ & $1.897 \mathrm{i}$ & $0.753 \mathrm{i}$ & $1.127 \mathrm{gh}$ & $0.62 \mathrm{i}$ & $1.51 \mathrm{i}$ & $0.95 \mathrm{j}$ \\
\hline $\mathrm{Mb} 4+\mathrm{Cb} 4$ & $1.997 \mathrm{f}$ & $0.797 \mathrm{f}$ & $1.203 \mathrm{e}$ & $0.673 \mathrm{f}$ & $1.63 \mathrm{e}$ & $1.007 \mathrm{~h}$ \\
\hline $\mathrm{Mb} 4+\mathrm{Cb} 9$ & $2.007 \mathrm{f}$ & $0.776 \mathrm{~g}$ & $1.177 \mathrm{f}$ & $0.654 \mathrm{~h}$ & $1.532 \mathrm{~h}$ & $0.96 \mathrm{i}$ \\
\hline $\mathrm{Mb} 7+\mathrm{Cb} 4$ & $2.11 \mathrm{~d}$ & $0.77 \mathrm{~h}$ & $1.134 \mathrm{~g}$ & $0.687 \mathrm{e}$ & $1.563 \mathrm{~g}$ & $1.017 \mathrm{~g}$ \\
\hline $\mathrm{Mb} 7+\mathrm{Cb} 9$ & $2.08 \mathrm{e}$ & $0.827 \mathrm{e}$ & $1.239 \mathrm{~d}$ & $0.667 \mathrm{~g}$ & $1.607 \mathrm{f}$ & $1.027 \mathrm{f}$ \\
\hline $\mathrm{Mb} 4+\mathrm{Cb} 4+\mathrm{Cb} 9$ & $2.12 \mathrm{~cd}$ & $0.843 \mathrm{~d}$ & $1.297 \mathrm{c}$ & $0.788 \mathrm{~b}$ & $1.67 \mathrm{~d}$ & $1.059 \mathrm{~b}$ \\
\hline $\mathrm{Mb} 7+\mathrm{Cb} 4+\mathrm{Cb} 9$ & $2.565 \mathrm{~b}$ & $0.987 \mathrm{~b}$ & $1.354 \mathrm{~b}$ & $0.777 \mathrm{c}$ & $1.734 \mathrm{~b}$ & $1.034 \mathrm{e}$ \\
\hline $\mathrm{Cb} 4+\mathrm{Mb} 4+\mathrm{Mb} 7$ & $2.107 \mathrm{~d}$ & $0.847 \mathrm{~d}$ & $1.23 \mathrm{~d}$ & $0.766 \mathrm{~d}$ & $1.673 \mathrm{~d}$ & $1.043 \mathrm{~d}$ \\
\hline $\mathrm{Cb} 9+\mathrm{Mb} 4+\mathrm{Mb} 7$ & $2.147 \mathrm{c}$ & $0.877 \mathrm{c}$ & $1.287 \mathrm{c}$ & $0.767 \mathrm{~d}$ & $1.72 \mathrm{c}$ & $1.054 \mathrm{c}$ \\
\hline $\begin{array}{l}\text { consortium of all the four } \\
\text { strains }\end{array}$ & $2.675 \mathrm{a}$ & $0.997 \mathrm{a}$ & $1.411 \mathrm{a}$ & $0.793 \mathrm{a}$ & $1.756 \mathrm{a}$ & $1.064 \mathrm{a}$ \\
\hline LSD & 0.0204 & $4.856 \mathrm{E} 03$ & 0.0141 & $4.580 \mathrm{E} 03$ & 0.014 & 3.948 E03 \\
\hline
\end{tabular}

Means sharing the same letter are not significantly different from each other (data is the mean of three repeats)

Mb4= Bacillus megaterium, Mb7= Pseudomonas aeruginosa, Cb4= Serratia spp., Cb9= Pseudomonas fluorescens

Table 6: Effect of consortium of bacterial strains on uptake of NPK by grains and straw of maize grown in pots

\begin{tabular}{|c|c|c|c|c|c|c|}
\hline Treatment & $\begin{array}{l}\text { N uptake } \\
\text { grain (mg } \\
\left.\text { pot }^{-1}\right)\end{array}$ & $\begin{array}{l}\text { N uptake } \\
\text { straw (mg } \\
\left.\text { pot }^{-1}\right)\end{array}$ & $\begin{array}{l}\text { P uptake } \\
\text { grain }(\mathrm{mg} \\
\left.\text { pot }^{-1}\right)\end{array}$ & $\begin{array}{l}\text { P uptake } \\
\text { straw (mg } \\
\left.\text { pot }^{-1}\right)\end{array}$ & $\begin{array}{l}\text { K uptake } \\
\text { grain (mg } \\
\left.\text { pot }^{-1}\right)\end{array}$ & $\begin{array}{l}\text { K uptake } \\
\text { straw (mg } \\
\text { pot }^{-1} \text { ) }\end{array}$ \\
\hline Control & 606.71 & 280.955 & 336.383 & 200.445 & 455.93 & 341.13 \\
\hline Mb4 & 786.3635 & 334.6332 & 443.5171 & 269.7508 & 586.11371 & 414.1808 \\
\hline $\mathrm{Mb} 7$ & 812.736 & 329.9499 & 472.8261 & 244.2601 & 605.319 & 412.1061 \\
\hline $\mathrm{Cb} 4$ & 792.7287 & 349.0617 & 448.2467 & 263.958 & 604.944 & 406.4043 \\
\hline Cb9 & 765.8189 & 343.4433 & 454.9699 & 282.782 & 609.587 & 435.5755 \\
\hline $\mathrm{Mb} 4+\mathrm{Cb} 4$ & 907.2371 & 378.1765 & 546.5229 & 319.3385 & 740.509 & 477.8215 \\
\hline $\mathrm{Mb} 4+\mathrm{Cb} 9$ & 894.1185 & 377.912 & 524.3535 & 318.498 & 682.506 & 467.52 \\
\hline $\mathrm{Mb} 7+\mathrm{Cb} 4$ & 931.354 & 371.371 & 500.5476 & 331.3401 & 689.9082 & 490.4991 \\
\hline $\mathrm{Mb} 7+\mathrm{Cb} 9$ & 984.048 & 405.23 & 586.1709 & 326.83 & 760.2717 & 503.23 \\
\hline $\mathrm{Mb} 4+\mathrm{Cb} 4+\mathrm{Cb} 9$ & 1111.728 & 448.6446 & 680.1468 & 419.3736 & 875.748 & 563.5998 \\
\hline $\mathrm{Mb} 7+\mathrm{Cb} 4+\mathrm{Cb} 9$ & 1283.783 & 540.2838 & 677.677 & 425.3298 & 867.867 & 566.0116 \\
\hline $\mathrm{Cb} 4+\mathrm{Mb} 4+\mathrm{Mb} 7$ & 1062.771 & 464.156 & 620.412 & 419.768 & 843.8612 & 571.564 \\
\hline $\mathrm{Cb} 9+\mathrm{Mb} 4+\mathrm{Mb} 7$ & 1103.773 & 480.8591 & 661.6467 & 420.5461 & 884.252 & 577.9082 \\
\hline $\begin{array}{l}\text { Consortium of } \\
\text { all the four } \\
\text { strains }\end{array}$ & 1491.848 & 553.8335 & 786.9147 & 440.5115 & 979.3212 & 591.052 \\
\hline
\end{tabular}

Mb4= Bacillus megaterium, Mb7= Pseudomonas aeruginosa, Cb4= Serratia spp., Cb9= Pseudomonas fluorescen

percentage of NPK than control. Uptake of nitrogen, rhizobacteria and CIB compete with pathogen to colonize 
the root, thus restrain the pathogen and help plant to grow successfully in fungus infested soil. Fungal pathogen stunted the growth and sometime fully destroyed the developmental activities of plant. Inoculation with selected strains of PGPR and CIB help plant to grow, survive and positively influence the ultimate yield of maize in infested soil. Healthy growth of the crop is responsible for better yield. Biotic stress stunted the growth which leads to the poor yield of the crop.

Under biotic stress, different mechanisms were adopted by bacteria to promote growth of the plant. They provide relief to the plant by improving nutrition (Peralta et al., 2013), producing requisite hormone to suppress the pathogens (Saharan and Nehra, 2011) and by releasing siderophore (Arruda et al., 2013). Siderophore production by bacteria is very important with respect to pathogen control. It chelates the micronutrients, necessary for growth and pathogenicity of the pathogens and creates famine of these nutrients for pathogens to kill them. It was also endorsed by other scientists who observed that siderophore producers support the plant against disease attack (Wani et al., 2007) and enable to bear biotic and abiotic stress (Usha et al., 2011).

Another way to control pathogen is the ability to produce antifungal enzymes. Therefore chitinase producing bacterial strains have better antifungal activities. Our selected strains were good chitinase producers and it was observed that better chitinase and siderophore producing strains helped plants to survive and produced higher biomass in fungus infested soil. These strains antagonized the pathogens up to $86 \%$ which was due to production of antifungal metabolites. It was observed previously that PGPR act as defensive mediators against soil-borne plant pathogens (Lowe et al., 2012) due to the production of antifungal enzymes (Laslo et al., 2012). Compost inhabiting bacteria, particularly fluorescent pseudomonads and certain Bacillus spp effectively controlled the root diseases (fungal and bacterial) of agricultural crops (Ahmadzadeh et al., 2004).

In fungus infested soil, consortium of bacterial strains helps plant to function normally by contending the pathogen. They compete with pathogen for food and space by root colonization and by producing various antibiotic compounds. They have multiple functions in the rhizosphere and approaching towards plant growth promotion. Suppression of pathogen through competition for food and space enables the bacteria to support the better growth and yield of the crop in fungus infested soil. Root colonization is important criteria to suppress the pathogen and biofilm is the measure of root colonizing ability of microbes. It is the biological response to compete for root niches and nutrients and inducing systemic resistance in host plants (Haas and Défago, 2005). In the current study, selected bacterial strains showed higher values for biofilm formation. Biofilm formation is important for plant microbe interaction to control the pathogen (Timmusk, 2005). It is a bio barrier on the roots against pathogens (Morikawa et al., 2006). Root length significantly increased by inoculation with consortium of beneficial bacteria. Our study exhibited that seed inoculation with consortia resulted in developed and improved root architecture due to which uptake of nutrients $(\mathrm{N}, \mathrm{P}$, and $\mathrm{K})$ is enhanced. The increased uptake of nitrogen, phosphorus and potassium was due to solubilization of nutrients (Ranjan et al., 2013), production of siderophore (Sayyed et al., 2010) and well developed root system (Karnwal, 2009) due to inoculation with consortium of bacteria strains (Figueiredo et al., 2010).

Results also showed the increase in root and shoot biomass by inoculation with bacterial consortia. PGPR has the capability to promote plant growth and productivity through synthesizing phytohormone, increasing the nutrient availability, antagonizing phytopathogens and decreasing metal toxicity (Burd et al., 2000). The improving effect of seed inoculation with bacterial consortia on shoot dry weight and yield of maize was reported by Shaharoona $e t$ al. (2006). Such an enhancement might be due to the ability of bacteria to fix nitrogen, solubilize the phosphate and production of growth regulators (Salantur at el., 2006). Consortium inoculation increased the leaf area responsible for efficient photosynthesis and finally the yield of the crop. It is due to well-developed root system, efficient root colonization and resultantly the uptake of water for photosynthesis. Elkoca et al. (2008) determined that dry matter, grain yield and phosphorus uptake was significantly higher by co-inoculation than single inoculated treatments in legumes. Other scientists also observed the increase in plant height and leaf area by inoculation with bacterial consortia (Govindappa et al., 2011). Increased growth was also observed in wheat (Salantur et al., 2006), tomato (Gravel et al., 2007), chickpea (Verma et al., 2010), fodder galega (Egamberdieva et al., 2010) and maize (Pacôme et al., 2013) due to co-inoculation. Under diseased condition it may be due to the production of siderophore, antifungal compounds, auxin biosynthesis and efficient root colonization. Biocontrol strategy depends on the nutrient management, better root colonization (biofilm formation) and production of siderophore and chitinase. Present study exhibited that selected strains of bacteria $(\mathrm{Mb} 4, \mathrm{Mb} 7, \mathrm{Cb} 4$ and $\mathrm{Cb} 9$ ) possessed these characteristics, therefore had suppressive effect on the pathogen which cause seedling blight in maize. Their combined activity showed higher efficiency for growth promotion in fungus infested soil than 
the single inoculation but consortium of all the four strains showed the best in results this contest.

\section{Conclusion}

Beneficial bacterial population played important role in growth and yield promotion through different mechanisms. They suppressed the pathogen through competition for food and space on root, production of antifungal metabolites and by inducing systemic resistance in plant. They promoted growth through solubilizing the nutrients and making it available to plant. However their efficiency may vary under different conditions. The selected bacterial strains suppressed the pathogen because they were screened against the Fusarium oxysporum which caused seedling blight in maize and their efficiency may vary with change in causal organism or disease. Their effectiveness in other crops may also be different. To avoid the harmful effect of pesticide the bacterial consortia may be extended in other crops under stressful condition. The selected strains may be tested under abiotic stresses because the characteristics described above, enabled them to promote growth under stressful condition. Nevertheless the given consortium of bacterial strains can effectively be used to increase the growth of maize in Fusarium infested soil.

\section{References}

Ahmadzadeh, M., A.S. Tehrani and K.T. Jahromi. 2004. Study on production of some antimicrobial metabolites by fluorescent pseudomonads. Iranian Journal of Agricultural Sciences 35(3): 731-739.

Arruda, L., A. Beneduzi, A. Martins, B. Lisboa, C. Lopes, F. Bertolo, L. Maria, P. Passaglia, L.K. Vargas. 2013. Screening of rhizobacteria isolated from maize (Zea mays L.) in Rio Grande do Sul State (South Brazil) and analysis of their potential to improve plant growth. Applied Soil Ecology 63: 15- 22.

Ayers, R.S. and D.W. Westcot. 1985. Water quality for agriculture. FAO irrigation and drainage papers 29 (rev. 1). FAO, Rome.

Bouffaud, M.L., M. Kyselkova, B. Gouesnard, G. Grundmann, D. Muller and Y. Moënne Loccoz. 2012. Is diversification history of maize influencing selection of soil bacteria by roots. Molecular Ecology 21: 195206.

Bulgarelli, D., K. Schlaeppi, S. Spaepen, E. VerLorenvan Themaat and P. Schulze-Lefert. 2013. Structure and functions of the bacterial microbiota of plants. Annual Review of Plant Biology 64: 807-838.

Burd, G.I., D. G. Dixon and B. R. Glick. 2000. Plant growth promoting rhizobacteria that decrease heavy metal toxicity in plants. Canadian Journal of Microbiology 33(3): 237-245.
Cardoso, R.A., L.T.A. Pires, T.D. Zucchi, F.D. Zucchi and T.M.A.D. Zucchi. 2010. Mitotic crossing-over induced by two commercial herbicides in diploid strains of the fungus Aspergillus nidulans. Genetic and Molecular Research 9: 231-238.

Carmen, B. and D. Roberto. 2011. Soil Bacteria support and protect plants against abiotic stresses, abiotic stress in plants - Mechanisms and Adaptations, Shanker (Ed.), ISBN: 978-953-307-394-1.

Chaparro, J.M., D. V. Badri, M.G. Bakker, A. Sugiyama, D.K. Manter and J.M. Vivanco. 2013. Root exudation of phytochemicals in Arabidopsis follows specific patterns that are developmentally programmed and correlate with soil microbial functions. PLoS ONE 8: e55731.

Charles, W. Bacon and dorothy M. Hinton. 2007. Potential for control of seedling blight of wheat caused by Fusarium graminearum and related species using the bacterial endophyte Bacillus mojavensis. Biocontrol Science and Technology 17(1/2): 81-94.

Chernin, L.S., M.K. Winson, J.M. Thompson, S. Haran, B.W. Bycroft, I. Chet, P. Williams and G. S. A. B. Stewart. 1998. Chitinolytic activity in Chromobacterium violaceum: substrate analysis and regulation by Quorum sensing. Journal of Bacteriology 180: 4435-4441.

Clark, V.L. and P.M. Bavoil. 1994. Methods in Enzymology 235(A), Academic Press, London, pp. 315-372.

Drogue, B., E. Combes-Meynet, Y. Moënne-Loccoz, F. Wisniewski-Dyé and C. Prigent-Combaret. 2013. Control of the cooperation between plant growthpromoting rhizobacteria and crops by rhizosphere signals in Vol.1 and 2, Molecul. Microbial Ecology and Rhizosphere. F.J.de Bruijn (ed) \& Sons, Inc.). 281294.

Duncan, D.B. 1955. Multiple range and multiple F-test. Biometrics. 11: 1-42.

Egamberdieva, D., G. Berg, K. Lindstrom and L.A. Rasanen. 2010. Co-inoculation of Pseudomonas spp. with Rhizobium improves growth and symbiotic performance of fodder galega (Galega orientalis L.). European Journal of Soil Biology 46: 269-272.

El Zemrany, H., S. Czarnes, P.D. Hallett, S. Alamercery, R. Bally and L. Jocteur Monrozier. 2007. Early changes in root characteristics of maize (Zea mays) following seed inoculation with the PGPR Azospirillum lipoferum CRT1. Plant Soil 291: 109-118.

Elkoca, E., F. Kantar and F. Sahin. 2008. Influence of nitrogen fixing and phosphate solubilizing bacteria on nodulation, plant growth and yield of chickpea. Journal of Plant Nutrition 33: 157-171. 
Erdogan, O. and K. Benlioglu. 2010. Biological control of Verticillium wilts on cotton by the use of fluorescent Pseudomonas spp. under field conditions. Biological Control 53: 39-45.

Falahian, F., Z. Oraghi Ardebili and H. Fahimi. 2007. Effect of mycorrhizal fungi on some defense enzymes against Gaeumannomyces graminis in Wheat. Pakistan Journal of Biological Sciences 10(14): 2257-2266.

Figueiredo, M.V.B., L. Seldin, F.F. de Araujo and R. L. R. Mariano. 2010. Plant growth promoting rhizobacteria: fundamentals and applications. Plant Growth and Health Promoting Bacteria, D.K. Maheshwari (ed.). DOI 10.1007/978-3-642-13612-2_2.

Gassmann, A.J., J. L. Petzold-Maxwell, R. S. Keweshan, M. W. Dunbar. 2011. Field evolved resistance to Bt maize by western corn rootworm. PLoS ONE 6: e22629.

Govindappa, M., V. Ravishankar Rai and S. Lokesh. 2011. Screening of Pseudomonas fluorescens isolates for biological control of Macrophomina phaseolina root rot of safflower. African Journal of Agriculture Research 6(29): 6256-6266.

Gravel, V., H. Antoun and R. J. Tweddell. 2007. Growth stimulation and fruit yield improvement of greenhouse tomato plants by inoculation with Pseudomonas putida or Trichoderma atroviride: Possible role of indole acetic acid (IAA). Soil Biology and Biochemistry 39(8): 1968-1977.

Haas, D. and G. Defago. 2005. Biological control of soil borne pathogens by fluorescent pseudomonads. Nature Reviews Microbiology 3: 307-319.

Hrynkiewicz, K., C. Baum and P. Leinweber. 2010. Density, metabolic activity and identity of cultivable rhizosphere bacteria on Salix viminalis in disturbed, arable and landfill soils. Journal of Plant Nutrition and Soil Science 173:747-756.

Jackson, M.L. 1967. Soil Chemical Analysis. Prentice-Hall, New Delhi.

Jing, Y.D., Z.L. He and X.E. Yang. 2007. Role of soil rhizobacteria in phytoremediation of heavy metal contaminated soils. Journal of Zhejiang University Science 8(3): 192-207.

Karnwal, A. 2009. Production of indol acetic acid by fluorescent pseudomonas in the presence of Ltryptophan and rice root exudates. Journal of Plant Pathology 91 (1): 61-63.

Katarzyna, H. and B. Christel. 2011. The Potential of Rhizosphere Microorganisms to Promote the Plant Growth in Disturbed Soils. Environmental Protection Strategies for Sustainable Development, pp.35-64.

Khan, M. R., S. Fischer, D. Egan and F. M. Doohan. 2006. Biological control of Fusarium seedling blight disease of wheat and barley. Phytopathology 96: 386-394.
Killani, A. S., R. C. Abaidoo, A. K. Akintokun and M. A. Abiala. 2011. Antagonistic effect of indigenous Bacillus subtilis on root/soil-borne fungal pathogens of cowpea. Science publications 3(3): 11-18.

Krieg, N.R. and J.G. Holt. 1984. Bergey's Manual of Systematic Bacteriology. Vol. 1. Williams and Wilkins, Baltimore, MD, USA.Pp. 694.

Kumar, V., M.V. Sarma, K. Saharan, R. Srivastava, L. Kumar and V. Sahai et al., 2012. Effect of formulated root endophytic fungus Piriformospora indica and plant growth promoting rhizobacteria fluorescent pseudomonads R62 and R81 on Vigna mungo. World Journal of Microbiology and Biotechnology 28: 595603.

Laslo, E., E. Gyorgy, G. Mara, E. Tamas, B. Abraham and S. Lanyi. 2012. Screening of plant growth promoting rhizobacteria as potential microbial inoculants. Crop Protection 40: 43-48.

Lowe, A., S. Raffery-McArdle and A.C. Cassells. 2012. Effects of AMF and PGPR root inoculation and a foliar chitosan spray in single and combined treatments on powdery mildew disease in strawberry. Agriculture and Food Science 21: 28-38.

Lugtenberg, B. and F. Kamilova. 2009. Plant-GrowthPromoting Rhizobacteria. Annual Review of Microbiology 63:541-56

Luria, S.E. and J.W. Burrous. 1995. Hybridization between Escherichia coli and Shigella. Journal of Bacteriology 74: 461-476.

Morgan, J.A.W., G.D. Bending and P.J. White. 2005. Biological costs and benefits to plant-microbe interactions in the rhizosphere. Journal of Experimental Botany 56: 1729-1739.

Morikawa, M., S. Kagihiro, M. Haruki, K. Takano, S. Branda, R. Kolter and S. Kanaya. 2006. Biofilm formation by a Bacillus subtilis strain that produces gpolyglutamate. Microbiology 152: 2801-2807.

Niranjan, R. S., S.N. Lavanya, K.N. Amruthesh, S.R. Niranjana, M.S. Reddy and H.S. Shetty. 2012. Histochemical changes induced by PGPR during induction of resistance in pearl millet against downy mildew disease. Biological Control 60: 90-102.

Olsen, S.R. and L.E. Sommers. 1982. Phosphorus. In: Method of Soil Analysis, Chemical and Microbiological Properties. American Society of Agronomy Madison. WI, USA. Part 2. (2): 403-430.

Pacôme, A., Noumavo1, Eméric Kochoni, O. Yédéou, Didagbé, Adolphe Adjanohoun, Marcellin Allagbé, Rachidatou Sikirou, W. Emma, Gachomo, Simeon O. Kotchoni, Lamine Baba-Moussa. 2013. Effect of different plant growth promoting rhizobacteria on maize seed germination and seedling development. American Journal of Plant Sciences 4: 1013-1021. 
Peeters, E., H.J. Nelis and T. Coenye. 2008. Comparison of multiple methods for quantification of microbial biofilms grown in microtiter plates. Journal of Microbiological Methods 72: 157-165.

Peralta, K.D., T. Araya, S. Valenzuela, K. Sossa, M. Martinez, H. Pena-Cortes and E. Sanfuentes. 2013. Production of phytohormones, siderophores and population fluctuation of two root-promoting rhizobacteria in Eucalyptus globulus cuttings. World Journal of Microbiology and Biotechnology 28: 20032014.

Pugliese, M., B.P.Liu, M.L. Gullino and A. Garibaldi. 2008. Selection of antagonists from compost to control soil borne pathogens. Journal of Plant Diseases and Plant Protection 115: 220-228.

Ranjan, A., M. Rajan, Mahalakshmi and M. Sridevi. 2013. Isolation and characterization of phosphate-solubilizing bacterial species from different crop fields of Salem, Tamil Nadu, India. International Journal of Nutrition, Pharmacology, Neurological Diseases 3(1): 29-33.

Ryan, J., G. Estefan and A. Rashid. 2001. Soil and Plant Analysis Laboratory Manual. Jointly published by the International Centre of Agricultural Research in Dry Areas (ICARDA), Aleppo, Syria and National Agricultural Research Centre (NARC), Islamabad.

Saharan, B.S. and V. Nehra. 2011. Plant growth promoting rhizobacteria: a critical review. Life Science and Medical Research 21:1-30.

Salantur, A., A. Ozturk and S. Akten. 2006. Growth and yield response of spring wheat (Triticum aestivum L.) to inoculation with rhizobacteria. Plant and Soil Environment 52(3): 111-118.

Sayyed, R.Z., N.S. Gangurde, P.R. Patel, S.A. Joshi and S.B. Chincholkar. 2010. Siderophore production by Alcaligenes faecalis and its application for growth promotion in Arachis hypogaea. Indian Journal of Biotechnology 9: 302-307.

Shaharoona, B., M. Arshad., Z.A. Zahir and A. Khalid. 2006. Performance of Pseudomonas spp. containing ACC-deaminase for improving growth and yield of maize (Zea mays L.) in the presence of nitrogenous fertilizer. Soil Biology and Biochemistry 38: 29712975.

Shukla, K.P., S. Sharma, N.K. Singh, V. Singh, K. Tiwari and S. Singh. 2011. Nature and role of root exudates: efficacy in bioremediation. African Journal of Biotechnology 10: 9717-9724.

Singh, K., J. C. Frisvad, U. Thrane and S.B. Mathur. 1991. An illustrated manual on identification of some seedborne Aspergilli, Fusaria, Penicillia and their mycotoxins. Danish Government Institute of Seed Pathology, Copenhagen, Denmark.
Steel, R.G.D., J.H. Torrie and D.A. Dicky. 1997. Principles and Procedures of Statistics-A Biometrical Approach (3rd Ed.) McGraw-Hill Book International Co., Singapore.

Tarkka, M., S. Schrey and R. Hampp. 2008. Plant associated micro-organisms. In: Nautiyal CS, Dion P (eds) Molecular mechanisms of plant and microbe coexistence. Springer, New York, pp. 3-51.

Timmusk, S., N. Grantcharova and E.G.H. Wagner. 2005. Paenibacillus polymyxa invades plant roots and forms biofilm. Applied and Environmental Microbiology 71: 7292-7300.

Usha, R.M., Arundhathi and G. Reddy. 2011. Bacillus cereus and Enterobacter cancerogenus screened for their efficient plant growth promoting traits rhizobacteria (PGPR) and antagonistic traits among sixteen bacterial isolates from rhizospheric soils of pigeon pea. African Journal of Microbiology Research 5(15): 2090-2094.

Verma, J., J. Yadav and K.N. Tiwari. 2010. Impact of plant growth promoting rhizobacteria on crop production. International Journal of Agriculture Research 11: 954983.

Vincent, J.M. 1947. Distortion of fungal hyphae in the presence of certain inhibitors.Nature 150:850.

Walker, V., O. Couillerot, A.Von Felten, F. Bellvert, J. Jansa, M. Maurhofer, et al., 2012. Variation of secondary metabolite levels in maize seedling roots induced by inoculation with Azospirillum, Pseudomonas and Glomus consortium under field conditions. Plant Soil 356: 151-163.

Wani, P.A., M.S. Khan and A. Zaidi. 2007. Effect of metal tolerant plant growth promoting Bradyrhizobium sp. (vigna) on growth, symbiosis, seed yield and metal uptake by green gram plants. Chemosphere 70: 36-45.

Wasim, A., D. Sengupta and A. Chowdhury. 2009. Impact of pesticides use in agriculture: Their benefits and hazards. The Journal of Interdisciplinary Toxicology 2(1): 1-12.

Yadav, J., J.P. Verma and K.N. Tiwari. 2010. Effect of plant growth promoting rhizobacteria on seed germination and plant growth chickpea (Cicer arietinum L.) under in Vitro Conditions, Biological Forum-Annual of International Journal. 2(2):15-18. 